\title{
The Power of Negative Thinking: Government Regulation and Economic Performance
}

\section{MURRAY I. WEIDENBAUM}

Let me start off with a proposition duly overstated - which should fit comfortably with the remarks of other contributors to this conference on supply -side economics: it is futile to focus so heavily on tax incentives to encourage economic activity at a time when the governmental regulatory apparatus is imposing such a vast and rapidly expanding array of obstacles to economic activity.

The lack of paralletism in my language is deliberate. It is not just a matter of the disincentives of regulation of fsetting some of the incentives which can be provided by tax reform. Rather, it is a case of insurmountable government-imposed barriers which any increases in the normal, after-tax rate of return can do little to hurdle.

For example, the most generous of tax credits will not help a company to market a product that has been banned by the government. The most liberal depreciation allowance will not assist a firm in obtaining the numerous permits which are essential to the operation of a new power plant. Indexing income tax rates will not encourage the job applicant who is turned aside by companies administering government-imposed quotas in their hiring. Nor will massive reductions in personal income taxes help the teenager who is priced out of the labor market by the latest increase in the compulsory minimum wage.

Of course, this is not truly a matter of either/or. We need not and should not choose between tax reform and regulatory reform. Rather, we should understand that the two go together. In practice, supply-side tax cuts and reductions of regulatory burdens are 
mutually reinforcing. Both can increase the capacity of the economy to produce goods and services, the willingness of investors to take risks, of management to innovate, and of workers to produce.

To put it less dramatically, but more specifically than I did in my opening statement, tax reform is a necessary but not sufficient condition for substantially improving the performance of the American economy. We must simultaneously deal with what I call the power of negative thinking - the ability of, or at least the tendency for, the regulatory apparatus (in truth I cannot call it a system) to make economic activity difficult to perform. So many government regulatory agencies have the power to say no to new economic undertakings; few, if any, have definite authority to say yes. To the typical entrepreneur, government is not a source of help, but the possessor of the power to stop or at least to delay and confuse. As a federal judge recently declared, "The federal bureaucracy is legally permitted to execute the Congressional mandate with a high degree of befuddlement as long as it acts no more befuddled than the Congress must reasonably have anticipated."

It is fascinating to consider the attitudes of the proponents of that increased regulation: they view the modern corporation simultaneously as venal and omnipotent. That is, they implicitly assume that society can impose an endless variety of so-called social responsibilities on the business firm without affecting its basic ability to carry on its economic function, that of meeting consumer needs for goods and services.

To bolster my point, let me cite high authority, a recent issue of the magazine Mother Jones. The editor was reporting on a conference of business executives that he had recently attended. He explained his surprise at the attitude that he had encountered. As he put it, "We had come to view executives as the sort of men who blithely market fire-trap cars, fill the Love Canal with lethal chemicals, dump hazardous products on Third World countries and conceal the dangers of asbestos from their workers... To have perpetrated so much, unscathed - surely they must be a strong, confident breed, boldly planning new drives for profits."

That is not satire, but journalism, I keep reminding myself. But the Mother Jones editor, to his surprise, found a different spirit among the executives, who "saw themselves as innocent, aggrieved producers - unfairly assaulted by environmentalists [and] regulatory agencies..." He went on to point out, "The corporate sector, we 
discovered, felt besieged. Barry Commoner, Ralph Nader, Leonid Brezhnev, Teddy Kennedy and Jane Fonda were all out to get them."

It is not my purpose today to evaluate the innocence or the guilt of American business executives (whatever that would mean), but to point out the economic consequences that result from the massive range of government intervention in economic activity - which, in turn, has resulted from the pressures of the self-styled public interest groups. Subsequently, I will try to show how any effective, supply-oriented approach to public policy can take account of this phenomenon.

\section{The Many Costs of Government Regulation}

Most public and professional attention to the costs of government regulation has focused on the direct burdens of complying with govermment directions. You may recall my estimate that, at the federal level, these costs were in the neighborhood of $\$ 100$ billion in 1979 and rising rapidly. Granted the imperfections of my rudimentary techniques - I note that nobody else has attempted to take on such a task - I now acknowledge the important costs of regulation that $I$ neglected to take into account in my computations.

Let me enumerate some of these costs. It will become clear soon enough why 1 did not include them in my numbers. I am referring to the induced effects of regulation, the most diffuse and elusive aspect of measuring the impacts of regulation. But for the policymaker, what is truly important is not the precise dollar quantities but the direction of the impacts. Clearly, most of these induced effects of regulation impair the basic ability of the American economic system to perform. Let me enumerate the key types of induced regulatory costs.

1. The innovative product and process research and development that is not undertaken because corporate research and development budgets increasingly are being devoted to what is termed "defensive research." Many companies report that they devote large and growing shares of their scientific resources-from one fifth to one half - to meeting regulatory requirements or avoiding running afoul of regulatory restrictions. Surely, the longer it takes for a new product to be approved by a government agency and the more costly and uncertain the approval process, the more likely that innovation will be delayed and the rate of innovation reduced.

Invariably, it is discouraging to the innovative instincts of business firms to undergo experiences like the one recently had by 
Monsanto, the chemical company, with its recyclable plastic bottle for soft drinks. The Food and Drug Administration banned this new product because it was made with acrylonitrile. The regulators say that if the bottles were filled with acetic acid (and not soda pop) and stored for six months at $120^{\circ} \mathrm{F}$., an infinitesimal amount of the acrylonitrile could leak into the solution-and that would constitute a carcinogenic (and hence unlawful) food additive. On the basis of this less than brilliant experiment, Monsanto closed down all the factories making the product and laid off several thousand workers.

But these problems are not just a matter of large companies or of one obstinate government agency. A small R\&D oriented company, Nutrilite Products, reported similar negative experiences. After repeated efforts to obtain approval for a new "biological" form of insect control (instead of the more environmentally hazardous but traditional "chemical" approaches), the company concluded, "We're going back to making vitamin supplements and trying to stay as far away as possible from the Enviromental Protection Agency." In effect, government is building what Lee Loevinger, former chairman of the Federal Trade Commission, calls "legal envelope' around existing technology."

2. The new investments in plant and equipment that are not made because of regulatory barriers and the diversion of investment funds to meeting government-mandated social requirements. The cost of potential new investments is raised by the uncertainties generated in the permit-approval process and by the cloudy future of new rounds of regulation. Delays surely have become the order of the day. In 1975, it took Deere and Company, the agricoltural equipment manufacturer, only three months to receive a complete environmental permit review for constructing a new plant. Currently, Deere estimates the lag at two years. Although the company has received most of the permits it has requested, it reports that EPA has insisted that these permits contain reopener clauses in case the agency adopts more restrictive standards in the future. In another instance, after noting that 42 different federal, state, regional, county, and municipal agencies regulate his new aquaculture company, George Lockwood, president of Monterey Abalone Farms, stated in a paper to the AAAS that the major problem is not the direct costs of compliance but "the great uncertainty" about whether any new activity will meet rapidly changing regulatory standards.

Professor Ossar Lindbeck of the University of Stockhotm has commented on this phenomenon which apparently is not unique to 
the United States. He points out that if laws and regulations change "violently" all the time, the returns accruing from correct speculation about the next moves of the regulatory authority often become higher than the returns from careful investment in skills, product development, choice of production technique, and marketing. Professor Lindbeck contends, and I tend to share his concern, that the sluggish behavior of investment activity in most Western economies during recent years is derived not only from low short-term profits, but also from increased uncertainty about future government policies and the future rules of the game.

The problems facing firms which introduce new technology are especially great. Here is the assessment of a task force of the U.S. Energy Resources Council on the overall impact of regulatory activity on the establishment of a new energy industry: "In summary, some of these [regulatory] requirements could easily hold up or permanently postpone any attempt to build and operate a synthetic fuels plant." The recent cancellation of the SOHIO pipeline project provides striking evidence that the regulatory uncertainties are not limited in their adverse impacts to new technologies or even controversial ones.

Where government approvals are forthcoming, we find that a rising share of company investment is being devoted to meeting governmentally imposed social requirements. In recent years, outlays mandated by EPA and OSHA have come to about 10 percent of new capital formation in American industry. In a pioneering study, Edward Denison estimated that the diversion of this amount of new capital resulted in business productivity in 1975 being 1.4 percent lower than it otherwise would have been. One percent may not seem like much but, in recent years, that would have been the difference between a rise and a fall in the overall productivity of the economy.

Moreover, we cannot always assume that the loss of private productivity is offset by an improvement in some area of social concern. For example, Armco Steel Corporation was required to install special scrubbing equipment at one of its plants to reduce the emission of visible iron oxide dust. The scrubber does succeed in capturing 21.2 pounds per hour of the pollutant. However, it is run by a 1,020-horsepower electric motor. In producing the power for that motor, the electric utility's plant spews out 23.0 pounds per hour of sulfur and nitrogen oxides and other gaseous pollutants. Thus, even though Armco is meeting government regulations on visible emissions, the air is actually 1.8 pounds per hour dirtier because of the government's regulatory requirements. 
The Armco case is no isolated example. Scrubbers are increasingly becoming required equipment for electric utilities that are attempting to comply with EPA regulations. The federal agencies, by being unable or unwilling to consider the adverse but indirect effects of their actions, are likely to produce more instances in which unintended but undesirable side effects swamp the benefits. Consider the sad story of the Pennsylvania Power Company. That utility has a new 825 -megawatt complex that utilizes scrubbers. In extracting the pollutants from coal, it produces 18,000 tons of sludge a day. To dispose of the sludge, the company has been forced to build a 350 -foot-high dam, the largest earth and rock enbankment east of the Mississippi River. Behind the dam, there is now a lake of sludge, which already covers 900 acres in a picturesque valley of Western Pennsylvania!

Moreover, the regulations issued under the 1977 Clean Air Act Amendments will slow down, if not halt, industrial expansion in many parts of this nation. If and when the rulings are fully enforced, failure of a state to win EPA approval of its detailed clean air plan will result in an absolute prohibition of any new industrial construction in that state.

\section{The workers that are not hired because federal regulations have} priced them out of labor markets. A variety of serious academic studies has shown that the steady increases in the statutory minimum wage have reduced teenage employment significantly below what it otherwise would have been-without a comparable offsetting increase in adult employment. The Davis-

Bacon Act yields similar results in government-financed construction - lower employment and higher inflation rates.

4. The immeasurable effects of government regulation on the basic entrepreneurial nature of the private enterprise system. To the extent that management's attention is diverted from traditional business concerns to meeting government requirements, a significant bureaucratization of corporate activity results. Many chief executives now report that one third or more of their time is devoted to governmental and public policy matters.

Donald Rumsfeld, chief executive of a major drug company and former Congressman and Secretary of Defense, has described very personally the pervasiveness of government involvement in business:

When I get up in the morning as a businessman, I think a lot more about government that I do about our competition, because government is that much involved - whether it's HEW, IRS, SEC, FTC, or FDA. I always understood the problem intellectually, but the specific inefficiencies that result from the government injecting itself into practically every aspect of our business - that is something one can feel only by being here. 
This bureaucratization of entrepreneurial activity, albeit undramatic, is not of modest dimensions. Professor Douglas North of the University of Washington contends that the key margin of decision making in our society today is access to government influence. As he describes the matter, the predictable result is "to shift the focus of the investment of resources into attempts to favorably influence the strategic government official or to prevent the enactment of government policies that will adversely affect the interest of groups." The point may be overstated. There are still many more opportunities for private undertakings. Moreover, the adverse public reaction to massive use of business resources in polities would, under present circumstances at least, be overwhelming. Nevertheless, North is indicating an important emerging development, especially in the case of the larger business organizations.

Furthermore, Professor Lindbeck, from his different vantage point, has made a similar observation. As he puts it, "there will be great temptations," particularly for large firms, to bargain with politicians over the rules and to seek various "deals" with governmental authorities. Lindbeck notes the risk of businesses entering into "zero-sum games" where they concentrate on bargaining with governments rather than trying to increase output.

\section{APPROACHES TO POLICY CHANGES}

It may, however, be easier to identify the regulatory problem areas than to develop effective strategies for change. At the outset, we must recognize the source of many of the pressures for regulation-the self-appointed, self-styled public interest groups. Large segments of the media, as well as many legislators, view these groups automatically as both "representatives" and as underdogs. This simpleminded attitude results in the characterization of people who disagree with them as the "heavies." But just because I may disagree with Ralph Nader or Jane Fonda should not inevitably be taken as my representing some special interest opposed to the public welfare. Why not think the unthinkable? It just may happen that, on occasion, Ralph (or Jane) may be wrong.

Many-but not all-representatives of the public interest groups. confuse their personal prejudices with the national well-being. Surely, I do not claim to represent the public interest. In all of my years in government, I never met a mortal man or woman who truly represented the public interest. As someone who was intimately involved in government policymaking, 1 know that 
making good policy is far more difficult than merely choosing, in a simpleninded fashion, between "public" or "consumer" interests (which are presumably good and to be supported) and business interests (which are presumably evil and to be opposed). Effective poticymaking consists not of dramatic confrontation, but of carefully balancing and reconciling a variety of legitimate interests - such as clean air and low inflation, safe products and high employment, healthy working conditions and rising productivity.

In addition, the one thing this new breed of interest groups lack is a sense of humor. For example, they attacked OSHA for stopping the distribution of one of its pamphlets. OSHA had issued a pamphlet on farm safety which treated farmers like dummies. One of the newspapers in the nation's farm belt answered with the following editorial in the form of a Dick and Jane book, the kind you read in the first grade. Let me read it so you can decide for yourselves.

\section{DICK AND IANE VISIT THE FARM}

See the book.

See the little book.

See the little OSHA book.

What is OSHA?

OSHA is your government.

OSHA is the Occupational Safety and Health Administration.

OSHA helps people.

OSHA helps people to be safe.

OSHA made the little book for farmers.

What does the little book say?

This is what it says:

"Be careful around the farm. . hazards are one of the main causes of accidents. A hazard is anything that is dangerous.

"Be careful when you are handling animals. Tired or hungry or frightened cattle can bolt and trample you. Be patient, talk softly around the cows. Don't talk fast or be loud around them. If they are upset, don't go into the pen with them.

"Be careful that you do not fall into the manure pits. Put up signs and fences to keep people away. These pits are very

dangerous." 
See the farmer.

See the farmer go to the mail box.

See the farmer get the little book.

The farmer can read.

The farmer can read big words.

The farmer can read long sentences.

The farmer knows about fences.

The farmer knows about manure pits.

Now the farmer knows about OSHA.

See the farmer kick the mail box.

Hear the farmer say bad words.

See the farmer throw the little book.

See the farmer throw the little book into the manure pit.

See OSHA.

See OSHA write.

See OSHA throw money into the manure pit.

Say bad words about OSHA.

Basically, we have to realize that the variety of regulatory activity requires a variety of reform approaches. Eliminating regulation makes good sense in those areas where the consumer is better served by market competition. Energy is a prime example. Eliminating the entire apparatus of energy price restrictions, allocation controls, entitlements, and reporting requirements would result in more domestic production, more conservation, and reduced imports of foreign oil. Deregulation of airlines, trucking, and railroads are also good examples of regulatory reform oriented to supply-side concerns.

For the social regulations, there is no good altenative to revising the basic statutes under which the regulations are promulgated. The zero-risk approach of the Delaney Amendment to the Food, Drug, and Cosmetic Act is a cogent example of unrealistic and unreasonable social regulation which can be effectively curtailed only by rewriting the law. Given the multiplication of regulatory statutes, what would truly help is, yes, yet another statute, one requiring computsory benefit/cost tests. Each agency should be required to demonstrate in advance that its rulings will generate more benefits to the nation than costs - - hopefully, that the marginal benefits equal the marginal costs and that it has chosen the most cost-effective approach.

The promulgation of rules, of course, is not the only means of accomplishing public objectives. As economists have been trying to 
explain to government decision makers, pollution taxes could constitute a far less costly method of achieving water quality objectives. Interestingly enough, the business community, which shows little enthusiasm for regulation, is adamantly opposed to this use of the price system. Not that it is necessarily relevant, but 1 note that environmental standards, unlike pollution taxes, tend to be rougher on new industries than on established facilities. But as we have learned over the years, the most adamant foe of government intervention eventually learns how to convert a government rule to a bartier to entry. As Lee Loevinger has noted, "Thus small enterprises are slowly squeezed out and barriers to entry are established by government fiat that would make an oldfashioned monopolist either envious or embarrassed."

In many other areas of government intervention, notably consumer product safety, an information strategy is an alternative to compulsory standards or product bans. Interestingly enough, this approach often is favored in consumer surveys, although not by the more vocal consumer organizations.

A word of caution: any realistic appraisal of government regulation must acknowledge that important and positive benefits have resulted from some of the regulatory activities - less pollution, fewer product hazards, a reduction in job discrimination, and other desirable goals of our society. But the "externalities" generated by federal regulation do not justify government attempting to regulate every facet of private behavior.

\section{CONCLUSION}

To sum up: the response of the economy to supply-oriented tax policy will be greatly enhanced by reducing the numerous regulatory obstacles to economic activity. Failure to eliminate or at least substantially cut back the regulatory inhibitions to work, invest, and produce will result in disappointing returns from tax policy changes.

Government policymakers must come to realize the lack of symmetry in the two different policy mechanisms: tax changes can provide strong incentives to undertake private economic activity, but regulation can provide a simple but effective veto. Too many of the debates on supply-side economic policy have ignored or at least deemphasized the crucial power of negative thinking on the part of the regulatory apparatus. 